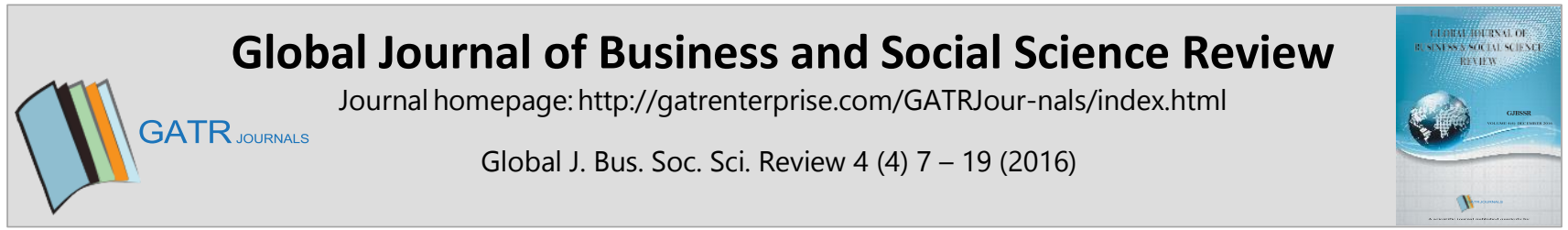

\title{
Students' Perceptions of the Academic and Social Benefits of Working with Cooperative Learning
}

\author{
Mohammed Almulla* \\ University of Leicester, Flat 38 Sanvey Mill Building, 1 Junior Street, LE1 4QB, Leicester, The UK
}

\begin{abstract}
Objective - Traditional teaching methods are no longer enough to prepare students to face the challenges and changes of an international society and to gain the skills needed for the contemporary labour market. Therefore, there is a need to implement alternative teaching methods in Saudi schools, such as cooperative learning to help learners gain personal and social skills and improve their learning. This study investigated Saudi high school learners' perceptions of cooperative learning based on its five principles (Johnson \& Johnson, 2014), and the benefits of working cooperatively in class.

Methodology/Technique - 97 students were involved in this study in one all-male high school in Saudi Arabia. Mixed methods (quantitative and qualitative) were used to collect the data, using a questionnaire and semi-structured interviews respectively.

Findings - The findings suggest that students seem to prefer to use cooperative learning instead of lecture-style mostly due to the perceived academic benefits it generates, among which were increased motivation, enhanced autonomy and responsibility towards learning, gaining thinking and problem solving skills, higher levels of understanding and long-term retention. Students also seem to agree that adopting the cooperative learning principles leads to social benefits such an enjoyment in learning, reduction in anxiety, increased confidence, and positive relationships among students.

Novelty - This paper has discovered and recommended that cooperative learning should be considered for implementation in Saudi schools instead of lecture-style in order to benefit students academically and socially.
\end{abstract}

Type of Paper: Empirical

Keywords: Communities of Practice, Cooperative Learning, Learning Benefits, Lecture-Style, Students' Perceptions.

JEL Classification: I20, I29.

\section{Introduction}

In Saudi Arabia, where the present investigation was carried out, the number of studies conducted on Cooperative Learning (CL) is still few and largely focus on assessment and the influence of CL on students' attainment by using experimental research designs to look into different curricula and stages of the Saudi education system. For example, Alreshidy (2008) conducted a study to examine the effect of CL on students' achievement in mathematics in secondary all-male schools in Hail, in the west part of the country. He found that CL approach increased achievement among learners in the experimental group more than in the control group. Alrehaily (2000)

\footnotetext{
* Paper Info: Revised: September 24, 2016

Accepted: October 16, 2016

* Corresponding author:

E-mail: ma649@le.ac.uk

Affiliation: School of Education, University of Leicester, UK
} 
aimed to examine the effect of using $\mathrm{CL}$ in science teaching on developing upper cognitive abilities of second year intermediate students as measured by the upper cognitive levels achievement test according to Bloom's taxonomy (Bloom et al., 1956). The experiment lasted two weeks, and the findings indicate the superiority of students in the CL groups (with and without feedback for some cooperative skills) in developing upper cognitive abilities when compared with students taught by the traditional method. Although such studies showed positive results in favour of CL, Almufadda (2006) found no evidence that the cooperative learning approach had some advantages over more traditional teaching methods. He aimed to investigate the influence of CL in comparison with lecture-style on students' attainment in 11-grade in the Islamic curriculum. While the majority of studies in the country discussed here, have indicated positive results in relation to achievement when using CL in comparison with traditional methods, some of these studies still argue that there is a need for further research on cooperative learning (Aljaser, 2002; Alreshidy, 2008). This paper tries to address this gap in CL research in the Saudi context by looking at high school learners' perceptions of cooperative learning and the academic and social benefits of working cooperatively in class in order to get some deep understanding regarding the effect of CL based on its five principles (Johnson \& Johnson, 2014).

\section{The Saudi education system and the relevance of change}

In Saudi Arabia, education in general stages (Table 1) is free for students between the ages of 6 and 18. The data are provided by the Saudi Ministry of Education (MOE, 2015).

Table 1. Saudi general education stages.

\begin{tabular}{|c|c|c|c|}
\hline Stage & Age-level & Length of stage in years & Official document \\
\hline Primary school & $6-12$ & 6 & $\begin{array}{c}\text { Primary education } \\
\text { certificate }\end{array}$ \\
\hline Secondary school & $12-15$ & 3 & $\begin{array}{c}\text { Secondary education } \\
\text { certificate }\end{array}$ \\
\hline High school & $15-18$ & 3 & High education certificate \\
\hline
\end{tabular}

Source: (MOE, 2015: The Establishment).

Education is not compulsory in Saudi Arabia, which means that students are not obliged to attend school and/or can withdraw from it whenever they choose. Moreover, every educational institution in the country is single-sex, even at university level (MOE, 2015). In Saudi Arabia, the Ministry of Education has total control over the educational system. This means that all schools follow the national curriculum and that materials for every subject are selected and published by the MOE and freely given to learners every term (MOE, 2015). Although the content of subjects is different from one stage to another, the subjects are still basically the same in all stages, such as languages, religion, science, mathematics, sports, arts, and history.

Besides the academic attainment, the aims of high school education include the development of some skills, such as research skills, cooperation, social skills and scientific and critical thinking (Alaqeel, 2013; Alhogail, 2011). However, according to Alsayegh (2007), using lecture-style and relying on transmission of information is unlikely to help and support students gain and achieve these objectives. This teaching method relies on teachers transferring knowledge to students, and individual learning for tests or examinations that can lead students to focus on knowledge and memorising skills over other skills (Almaliki, 2010). As a result, there is a perceived need to implement alternative teaching methods in Saudi schools, such as cooperative learning, in order to help learners gain personal and social skills and achieve the aims mentioned above.

According to Alsayegh (2007), educational systems in Saudi schools face many challenges. For example, technology is not often used in learning because this it is either not available or teachers do not know how it could be used. In addition, the students who graduate from schools and universities do not meet the needs of the job market while teachers at schools and universities still use traditional teaching methods, such as lecture-style, 
which are no longer enough to provide students the skills and support they need. In the last decade of the twentieth century and the first decade of the twenty-first century, the economic systems, as well as socio-cultural contexts, have changed due to a number of factors, such as technology, globalization, and economic competition (Alhadi, 2013), which have played a crucial role in educational change. As a result, educators have been advancing new ideas and concepts in the field of education related to the knowledge and the important skills individuals need to learn (Alsayegh, 2007). Supported by the developments in the teaching and learning theories, a change from teacher-centred to student-centred approach could be achieved with a consistent teacher training and education programme focusing on collaborative and cooperative teaching methods and use of new technologies in education. The development of creative and critical thinking skills can be promoted through activities that foster interdependence and student engagement in cooperative situations (Svalberg, 2012).

On the other hand, changes in the assessment and paths of progression cannot be reformed without implementing significant changes in the schools' rules and regulations, which in turn are determined at national level by the Ministry of Education. Many aspects of education, such as teaching methods, curriculum development, assessment, teachers training, and finance, are in the process of reform and development (Levin, 2001). However, effective educational change is not easy and simple to accomplish so it is important to investigate what is happening at schools both at local and national levels (Fullan, 2007). Taking these challenges into consideration, the local department of education in a city in Saudi Arabia provided some Saudi high schools with in-service training on using CL based on the five principles suggested by Johnson and Johnson (2014) in order to improve and change their teaching methods from lecturing method to CL. The aim of this paper is to investigate their students' perceptions of cooperative learning and the academic and social benefits of working cooperatively in class in comparing with using lecturing method.

\section{Theory and practice}

Learning theories profoundly affected educational practices (Schunk, 2014). A number of teaching methods are now available to practitioners and can be implemented in classrooms, such as lecture-style (direct instruction), discussion and debates, problem solving, personalised learning and cooperative learning. It can be argued that teaching approaches that apply direct instruction are highly influenced by behaviourism (Pavlov, 1934; Skinner, 1938; Thorndike, 1932) and cognitivist theories (Muijs \& Reynolds, 2011) whereas cooperative learning is seen to have its foundations in constructivism and developments in social-constructivist (Piaget, 2001), social-cultural (Vygotsky, 1978) and social-interdependence (Deutsch, 1949) theories.

Johnson and Johnson (2014) also argue that in cooperative learning classes students should work together in order to maximize each other's knowledge and achieve a shared goal. Learners search for outcomes that are valuable to all, negotiate material with each other in order to help one another understand the task and content, and encourage hard work. In the present study, the term cooperative learning is understood as learners working together in groups in order to accomplish specific goals through activities that are structured, controlled, and directed by the educators. Johnson and Johnson (2014) propose the adoption of five core principles to make CL effective: positive interdependence or group goal; individual accountability; promotive interaction; social skills; and group processing.

Another notion closely related to cooperative learning is the concept of communities of practice. In their seminal work, Lave and Wenger (1991) propose the concept of communities of practice and situated learning to explain the interactions individuals create in groups in order to engage in activities in their everyday lives. A distinction needs to be made between naturally occurring communities of practice, where members spontaneously come together, and institutional communities of practice, which depend on a structural set-up (Busher et al, 2014). In naturally occurring communities of practice, members tend to work collaboratively and their relationships tend to be less hierarchical and planned. On the other hand, set-up communities of practice tend to work more cooperatively, since their organisation and activities depend on well-defined and organised tasks. Intrinsic to the concept of community of practice is also the ideas of learning and identity. Members of a community of practice engage in common activities as a way of giving meaning to their experiences in the world, talk about their 
practices and shape their identities as members of a social group. Lave and Wenger's conceptualisation has had profound implications for the way educators see learning and much research has been done in various contexts based on the concept of communities of practice and learning communities (Barton \& Tusting, 2005; Hughes et al., 2007; Kimble et al., 2008).

A number of researchers indicate that learners can socially and academically benefit from working in small cooperative groups (Cavanagh, 2011; Farzaneh \& Nejadansari, 2014; Johnson et al., 2010). One possible reason for such positive findings is the adoption of Johnson and Johnson's five principles of using cooperative learning discussed here (Johnson et al., 2010). These five principles of CL (Johnson \& Johnson, 2014) that teachers have been trained to use are similar to the features of communities of practices, such as active engagement with content, reflection, conflict solving, and collaborative work (Barab \& Duffy, 2000). Implementing the five principles may thus lead to academic and social benefits to students (Johnson et al, 2010) and the development of a learning community (Barton \& Tusting, 2005; Hughes et al., 2007; Kimble et al., 2008). So, the class can be seen as the community of learning. Some of the benefits that have been suggested are discussed in this section and although they are presented in this paper in distinct segments, they are, in fact, all interconnected and in 'reciprocal relationship' (Johnson et al., 2007, p.21). Such reciprocity is largely created by interaction, which is the common factor behind such benefits. Interaction is also the aspect, which perhaps most differentiates cooperative and collaborative learning from other more teacher-centred approaches to teaching and learning. Interaction and engagement with content in a social environment are seen as key factors in the creation of learning communities. The implementation of cooperative learning principles may lead to some noticeable academic and social benefits.

\section{The academic benefits of $C L$}

According to VCSMR and Rao (2013), a main feature distinguishing cooperative learning approaches from other learning approaches is the opportunity for promotional interaction between learners. Interaction is considered to be an instructional strategy, which depends on more participation and discussion between learners in the classroom and allows them to learn from each other (Idowu, 2013). Interaction among learners in tasks is very likely to help promote better achievement as students could learn from each other when they discuss and engage in dialogue about the content (Gillies \& Khan, 2008). Such improvement in terms of achievement, promoted by interaction, is the result of better understanding of content (Johnson \& Johnson, 2009; Zakaria et al., 2013) and this can be connected to learners' ability to cognitively engage with ideas and concepts and to be able to critically consider them. Therefore, studies on how cooperative learning can improve understanding of the subjects studied should also consider how promotive interaction and positive interdependence encourage the development of learners' cognitive skills and team effort to attain joint goals. Understanding of content can be connected to learners' ability to cognitively engage with ideas and concepts and to be able to critically consider them. Therefore, studies on how cooperative learning can improve understanding of the subjects studied could also consider how such interaction promotes the development of learners' higher order thinking and problem solving skills. According to Gillies, (2008), such critical thinking could be stimulated in learners through the high level of debating between team members. Some researchers point out that those learners who are involved in cooperative learning approaches show increased academic achievement compared to other working in more traditional ways (Tran, 2014; Zakaria et al., 2013). Although literature in the field of cooperative and collaborative learning, as well as the empirical studies previously discussed, seem to confirm the theory that promotive interaction leads to better understanding of content and a higher level of critical thinking, it must be acknowledged that there are considerable difficulties in trying to measure learner's understanding of content. In most educational contexts, such as in Kuwait (Sarkhouh, 2007), Syria (Shaiban, 2009) and Turkey (Aydin, 2011), the assessment of how much students have learnt is still done through tests and high levels of understanding are usually associated with higher test scores.

Retention is one of the factors that may lead to higher academic achievement. According to McCauley and McClelland (2004), in traditional lecture-style teaching, when note taking is students' main task and information has been memorized, knowledge is only stored in the short-term memory. Berrett (2012, p.2) supports McCauley 
and McClelland's idea by indicating that such form of delivery "set up a dynamic in which students passively receive information that they quickly forget after the test". In contrast, in cooperative learning environments learners retain information longer than learners who are taught by other teaching methods (Bukunola \& Idowu, 2012; Johnson \& Johnson, 2009; Tran, 2014). Cooperative learning approach may also increase time on-task by engaging learners' attention and decrease off-task behaviour (Blatchford et al., 2007; Johnson \& Johnson, 2009). In addition, learners can be more on-task group behaviours (taking turns, sharing materials, group discussion of content) (Blatchford et al., 2007). It may also lead to increased learner motivation as student can find academic activities meaningful and attempt to academically benefit from them (Pan \& Wu, 2013). Yet, work independently can also lead to positive learning strategies (Duren \& Cherrington, 2010) and some studies claim that there is no significant difference in terms of students' motivation between classes implementing cooperative learning approach or using traditional methods (Tan et al, 2007). Finally, CL approaches are thought to conduct to greater autonomy and responsibility. Benson (2007) indicates that autonomous learners should take the responsibility to determine the purpose, the material and the strategy of their learning. They should monitor the progress of their learning and evaluate the outcomes. The idea of autonomous learners, who have the right and power to learn for themselves, is considered an essential principle by a number of proponents of learner autonomy (Smith, 2008). Learner autonomy can work at individual level but also emerge within the social context (Smith, 2008). According to Dam et al. (1990, p.102), learner autonomy is "a capacity and willingness to act independently and in cooperation with others, as a social, responsible person". Kohonen (1992) clarifies the idea of emerging autonomy within social contexts by indicating that autonomy "includes the notion of interdependence that is, being responsible for one's conduct in the social context: being able to cooperate with others and solve conflicts in constructive ways" (p.48).

\section{The social benefits of $C L$}

According to proponents of cooperative learning, using such approach should be maximized in the class in order to enhance positive interpersonal relationships between learners (Johnson et al., 2010; Tran \& Lewis, 2012) whereas individualistic and competitive learning should be minimized (Johnson \& Johnson, 2008b). The wholeclass method may isolate learners and create competition, which in turn may lead learners to focus on extrinsic motivation to achieve higher academic attainment than their peers. Conversely, a cooperative learning approach may enhance intrinsic motivation and interest (Shaaban, 2006). Cooperative learning is likely to lead to "greater interpersonal liking, group cohesion, valuing of heterogeneity, and task-oriented and personal support" (Johnson \& Johnson, 2008a, p. 2). Moreover, many teachers point out that they know their learners much better in cooperative learning environments. When academic staff observe learners working in small teams and then intervene this is likely to produce more informal and personal interactions between the teachers and the learners than in a lecture-style environment (Johnson et al., 2010). There seems to be a close relation between positive self-concept and positive self-esteem, so learners who believe they can do a number of things well are very likely to feel better about themselves (Taylor et al., 2007). Learners' self-esteem can be affected by how well learners attain progress in the class, how they interact to each other, and how they are liked by their peers (Slavin, 1995). It can be noted that self-esteem relates to both academic achievement and social interaction, and when learners see themselves as successful learners, their self-esteem is likely to increase (Peterson \& Miller, 2004).

CL approaches may also promote anxiety reduction and learning enjoyment. Anxiety could be defined as an unhappy emotional condition characterized by feeling of stress, worry and fear (Hockenbury \& Hockenbury, 2012). Anxiety is considered one of the main barriers to productivity and the creation of positive relationships among learners. It can lead students to egocentric preoccupation with their self and disruption of their cognitive thinking (Johnson et al., 2010). In traditional classroom environments, there are some situations that may lead to an increase in learners' anxiety. According to Crandall (1999), when learners work together, more time is available for them to think, share their views with their classmates, obtain feedback from other learners, and correct their own mistakes. Such interaction is likely to reduce the level of learners' anxiety and even increase their willingness to answer the educators' questions in front of their peers. Collaborative and cooperative tasks, 
however, may also create anxiety, especially when there is a "misalignment of performance expectations within teams" (Favor, 2012, p.157). Reduction of anxiety may be directly associated to increase in learning enjoyment. Some studies reveal that cooperative learning could positively affect learners' attitudes towards learning. The findings of a study conducted by Cavanagh (2011) show that learners' agree that cooperative learning activities helped them maintain enjoyment and interest in the sessions. The main reasons were that diversity of activities that 'broke up the time' and 'kept [learners] alert and thinking' by 'involving' (p.28) them in the classroom tasks.

\section{Research setting and methodology}

The current study was conducted in one state male high school in a city in Saudi Arabia where seven teachers who received in-service formal teacher training on using cooperative learning based on the five principles (Johnson \& Johnson, 2014). The number of students in the second term of 2015 was 562 who are in Year 10, 11, 12 high school (ages 16-18) which, according to the school principal, divided into mixed-ability classes. In total, there were 97 male students involved in the present study in the three classes were cooperative learning was used by teachers of some subjects. 37 students were in Year 10 class (age 16), 32 students were in Year 11 class (age 17) and 28 students were in Year 12 class (age 18). When the data was collected, students in Year 10 were being taught three subjects by CL, Maths, Biology and Arabic. In Year 11, students were being taught Chemistry and Maths by CL, whereas in Year 12 CL lessons were being given in Maths, English and Chemistry. Other subjects in these three classes were taught by other teachers by using lecturing methods.

In Year 10, students had been taught by CL for less than one semester. In Year 11, 87.1\% (27 students) were taught by cooperative learning for one year, with some new students who had different previous experience with CL joining the groups. In Year 12, 23 students (82.1\%) were taught by using CL for one and a half year while $17.9 \%$ (5 students) had been using CL for just one year (Table 2).

Table 2. Number of students taught by cooperative learning by period of time.

\begin{tabular}{|c|c|c|c|c|c|}
\hline Year & $\begin{array}{c}\text { Less than one } \\
\text { semester }\end{array}$ & $\begin{array}{c}\text { One } \\
\text { semester }\end{array}$ & One year & $\begin{array}{c}\text { One and half } \\
\text { year }\end{array}$ & Total \\
\hline Year 10 & 33 & 0 & 0 & 0 & 33 \\
$(100 \%)$ & $(0 \%)$ & $(0 \%)$ & $(0 \%)$ & $(100 \%)$ \\
\hline Year 11 & 1 & 3 & 27 & 0 & 31 \\
& $(3.2 \%)$ & $(9.7 \%)$ & $(87.1 \%)$ & $(0 \%)$ & $(100 \%)$ \\
\hline Year 12 & 0 & 0 & 5 & 23 & 28 \\
& $(0 \%)$ & $(0 \%)$ & $(17.9 \%)$ & $(82.1 \%)$ & $(100 \%)$ \\
\hline
\end{tabular}

All these CL classes were considered to be mixed-ability classes. It seems that most students in three years were high-achieving students since a high percentage in each Year scored between 80 and 100 in the 2014 academic year general grade (Table 3), which in the Saudi Arabian system consists of the average marks of all subjects.

Table 3. Last year's grade

\begin{tabular}{|c|c|c|c|c|c|c|}
\hline Grade & $0-49$ & $50-64$ & $65-79$ & $80-89$ & $90-100$ & Total \\
\hline Year 10 & 0 & 2 & 3 & 11 & 17 & 33 \\
& $(0 \%)$ & $(6.1 \%)$ & $(9.1 \%)$ & $(33.3 \%)$ & $(51.5 \%)$ & $(100 \%)$ \\
\hline Year 11 & 0 & 0 & 5 & 7 & 19 & 31 \\
& $(0 \%)$ & $(0 \%)$ & $(16.1 \%)$ & $(22.6 \%)$ & $(61.3 \%)$ & $(100 \%)$ \\
\hline Year 12 & 1 & 0 & 4 & 8 & 15 & 28 \\
& $(3.6 \%)$ & $(0 \%)$ & $(14.3 \%)$ & $(28.6 \%)$ & $(53.6 \%)$ & $(100 \%)$ \\
\hline
\end{tabular}

The findings of this study come from students' questionnaires and interviews. From the 97 student participants, 95 answered the questionnaire, however, only 92 were considered in the data analysis. Three of the questionnaire 
responses were incomplete and were, therefore, excluded from consideration. For the interviews, three students from each year were selected: S1-S3 from Year 10; S4-S6 from Year 11; and S7-S9 from Year 12.

This study adopted a mixed methods approach by collecting both quantitative and qualitative data. Descriptive statistics was used to examine quantitative data collected from the closed questions in the students' questionnaire. The data was converted into percentages to identify recurrent themes. The data were then analysed in terms of frequencies, percentages, and cross tabulation (Bryman, 2016) to compare quantitative data from different Years (Appendix - Table 1 and 2). The percentage and frequencies helped me understand and observe the outcomes from the students' answers regarding their perceptions in relation to academic and social benefits of working cooperatively. Questionnaire open questions followed some of the closed questions and were intended to gather more detailed information on students' opinions and perceptions. However, students did not provide any relevant information in the open questions. Qualitative data collected from semi-structured interviews with students were submitted to thematic analysis (Bryman, 2016), considering the interview questions for the pre-coded main themes according to Johnson and Johnson's (2014) five principles of cooperative learning. The findings of the students' questionnaire were analysed before analysing the students' interviews in order to add other questions in the interview after analysing the findings of the questionnaire.

\section{Findings}

\subsection{General perceptions}

Regarding general perceptions of CL, the questionnaire findings show that the majority of students in the three classes had positive views of CL and either agreed or strongly agreed with the affirmative statements presented. In general, students in all three Years seemed to like cooperative learning, with more than half of the respondents in Year 10 being quite positive about it (60.6\% / 20 students) but it is also observed that in Year 11, 32.3\% (10 students) were very positive about it (strongly agree) in comparison to just $15.2 \%$ (5 students) in the first year. When asked whether they preferred to be taught by cooperative learning or traditional methods, the majority of students in all three years indicated that they preferred CL by either agreeing (Year 10: 42.4\% / 14 students; Year 11: 61.3\% / 19 students; Year 12: 46.4\% / 13 students) or strongly agreeing (Year 10: 30.3\% / 10 students; Year 11: 19.4\% / 6 students; Year 12: 32.1\% / 9 students) with the statement (Table 4).

Table 4. Students' general perceptions of CL

\begin{tabular}{|c|c|c|c|c|c|c|}
\hline Questionnaire statements & The class & $\begin{array}{c}\text { Strongly } \\
\text { agree }\end{array}$ & Agree & Not sure & Disagree & $\begin{array}{c}\text { Strongly } \\
\text { disagree }\end{array}$ \\
\hline \multirow{3}{*}{$\begin{array}{c}\text { I like cooperative } \\
\text { learning } \\
\text { in the classroom }\end{array}$} & Year 10 & $\begin{array}{c}5 \\
(15.2 \%)\end{array}$ & $\begin{array}{c}20 \\
(60.6 \%)\end{array}$ & $\begin{array}{c}4 \\
(12.1 \%)\end{array}$ & $\begin{array}{c}2 \\
(6.1 \%)\end{array}$ & $\begin{array}{c}2 \\
(6.1 \%)\end{array}$ \\
\cline { 2 - 7 } & Year 11 & $\begin{array}{c}10 \\
(32.3 \%)\end{array}$ & $\begin{array}{c}13 \\
(41.9 \%)\end{array}$ & $\begin{array}{c}4 \\
(12.9 \%)\end{array}$ & $\begin{array}{c}3 \\
(9.7 \%)\end{array}$ & $\begin{array}{c}1 \\
(3.2 \%)\end{array}$ \\
\cline { 2 - 7 } & Year 12 & 6 & 15 & 6 & 1 & 0 \\
$(21.4 \%)$ & $(53.6 \%)$ & $(21.4 \%)$ & $(3.6 \%)$ & $(0.0 \%)$ \\
\hline \multirow{3}{*}{$\begin{array}{c}\text { I prefer to be taught by } \\
\text { cooperative learning to } \\
\text { traditional methods }\end{array}$} & Year 10 & $\begin{array}{c}10 \\
(30.3 \%)\end{array}$ & $\begin{array}{c}14 \\
(42.4 \%)\end{array}$ & $\begin{array}{c}5 \\
(15.2 \%)\end{array}$ & $\begin{array}{c}2 \\
(6.1 \%)\end{array}$ & $\begin{array}{c}2 \\
(6.1 \%)\end{array}$ \\
\cline { 2 - 7 } & Year 11 & 6 & 19 & 3 & 3 & 0 \\
$(19.4 \%)$ & $(61.3 \%)$ & $(9.7 \%)$ & $(9.7 \%)$ & $(0.0 \%)$ \\
\cline { 2 - 7 } & Year 12 & 9 & $\begin{array}{c}13 \\
(32.1 \%)\end{array}$ & $\begin{array}{c}4 \\
(46.4 \%)\end{array}$ & $\begin{array}{c}1 \\
(14.3 \%)\end{array}$ & $\begin{array}{c}1 \\
(3.6 \%)\end{array}$ \\
\hline
\end{tabular}

The statistical findings are corroborated by data from the interviews. Some students indicated reasons behind their preference for the CL lessons. For example, S3 (Year 10) said that, "I actively and cooperatively work with my group members in order to understand a specific piece of information. This is very enjoyable to me." Students also seemed to prefer to be taught by cooperative learning because they benefited from it more than from 
traditional teaching methods. For instance, S8 (Year 12) said, "the atmosphere helps to create new friendships and makes cooperative learning quite fun and usually I get good grades better than I get by using lecturing method." On the other hand, there were some students in Year 10 (12.1\% / 4 students), Year 11 (12.9\% / 4 students) and Year 12 (21.4\% / 6 students) who were not sure about liking cooperative learning. Moreover, less than $10 \%$ of students in all three years either disagreed or strongly disagreed with this statement. There was also a small percentage of students who did not express their preference in relation to the CL or traditional teaching methods.

\subsection{Students' perceptions of academic benefits}

Data collected shows that the majority of the students in the three classes believed they benefited from using cooperative learning more than when having lecture-style lessons (Appendix - Table 1). The majority of students in Year 10, Year 11 and Year 12 either agreed (Year 10: 51.5\% / 17 students; Year 11: 41.9\% / 13 students; Year 12: 46.4\% / 13 students) or strongly agreed (Year 10: 24.2\% / 8 students; Year 11: 38.7\% / 12 students; Year 12: $35.7 \%$ / 10 students) with the statement that they understand the content of the lesson better when it is delivered by CL rather than by lecture-style. For instance, S8 (Year 12) said that his "teammates explain to me the sections that I cannot understand. If I encounter a difficulty in understanding the lesson, I seek help from them through mutual discussion". S6 (Year 11) also commented on the peer learning aspect saying that when they engaged "in discussion, dialogue and explanation in order to arrive at information to answer the question given by the teacher" and that he could understand from his "teammates more than from teacher."

The majority of the students in three classes felt that using CL helped them with thinking skills more than lecturing method (Appendix - Table 1). For example, S9 (Year 12) commented that in the cooperative learning students worked to "understand the information and exchange ideas with group members using thinking skills to make correlations, analysis of answers and draw conclusions". S5 (Year 11) said "In the traditional method, I do not find out information by myself. I do not use thinking skills and so, my comprehension is lower".

A higher percentage of students in all classes agreed (Year 10: 36.4\% / 12 students; Year 11: 41.9\% / 13 students; Year 12: 39.3\% / 11 students) or strongly agreed (Year 10: 30.3\% / 10 students; Year 11: 22.6\% / 7 students; Year 12: 28.6\% / 8 students) that using CL helped them with problems solving skills more than lecturestyle (Appendix - Table 1). As an illustration, S1 (Year 10) said that "after identifying of the tasks questions, I suggest an answer and my teammates suggest a different answer. We discuss the answers together and analyze them."

In addition, the majority of the students in all three years thought that CL helped them with the retention of the lesson content (memory) more than lecturing method (Appendix - Table 1). For example, S2 (Year 10) said he believes that such retention is due to the fact that there is a process where, "I explain the information to my group members. This makes me reiterate the piece of information more than once, and it helps me remember it later".

Furthermore, high percentages of students in three classes either agreed or strongly agreed that CL increased their learning motivation in comparison with lecture-style (Appendix - Table 1). Years 11 and 12 figures show that there is a difference of more than 10 percentage points compared to students who strongly agreed with the statement in Year 10. For example, S5 (Year 11) explained that "when the teacher presents the lesson while I passively listen to him, I get bored and I feel sleepy. However, when I work on the task with my group members, this increases my motivation to learn."

Although most students in all three years seemed to believe that CL encouraged them to be autonomous learners with the questionnaires findings showing a much higher percentage of students in Year $12(60.7 \%$ / 17 students) agreeing with the statement. The combined figures for 'agree' and 'strongly agree' reach $82.1 \%$ (23 students). A possible explanation for this difference is that the majority of the students in Year 12 have been using CL for one and half year compared to students in Year 11 (one year) and in Year 10 (less than one semester). It is probable that some students need more time and experience with cooperative learning to benefit from it. 
Finally, the majority of the students in Year 11 and 12 indicated that CL increased their achievement test scores compared with lecture-style method. However, although students in Year 10 agreed (21.2\% / 7 students) or strongly agreed (15.2\% / 5 students) with that most of them (51.5\% / 17 students) said that they were not sure about increasing their achievement test scores with CL. In contrast, in Year 12, where students had been using CL for more than one year and had already gone through the assessment process, the percentage of participants who agreed with the statement is $53.6 \%$ (15 students) and those who strongly agreed is $25 \%$ ( 7 students).

\subsection{Students' perceptions of social benefits}

When it comes to social outcomes, data collected shows that the majority of the students in the three classes benefited from using cooperative learning more than lecture-style (Appendix - Table 2). The majority of the students thought that CL helped them with interpersonal relationships more than the lecturing method. For instance, S2 (Year 10) said working in a group "creates an opportunity to know other students. I now know some students in my team who I did not know them before and we have a good relationship with each other".

In terms of increasing the self-esteem, the majority of the students in all three years felt that using CL helped them develop it more than the lecturing method. The number of students in Year 12 that strongly agreed with it is higher than the other previous years (42.9\% / 12 students) (Appendix - Table 2). Since increasing self-esteem is long-time process, this is probably the reason for such figures being higher in the group, which had been using CL for more than one year. For instance, S9 (Year 12) commented that "I and my teammates have got used to working independently, searching for information and understanding it without reliance on the teacher. This has enhanced my self-esteem".

Most students-participants in all Years investigated indicated that using CL helped them with reducing anxiety in comparison with the lecturing method (Appendix - Table 2). As an illustration, S9 (Year 12) said, "even if it is difficult, my teammates will help me. I am not worried to be selected by the teacher to answer or explain anything related to lesson content." When asked about their enjoyment in learning, once again responses where highly positive with small differences between Years but still with all three classes agreeing or strongly agreeing that CL increased their pleasure in learning more than when taught by lecture-style (Appendix - Table 2). For example, S7 (Year 12) mentioned that "learning through working with my group members and talking to them are real fun and the teacher encourages us to do that."

\section{Conclusion}

The findings of this investigation suggest that the kind of teaching method that teachers implement in their classroom can have an impact on students' learning. From participant-students' perceptions, implementing CL based on its five principles (Johnson \& Johnson, 2014) is likely to lead to academic and social benefits to students. Since the five principles are similar to some features of community of practices (Barab \& Duffy, 2000), this can also lead the classroom to be seen as a community of learning. In general, students seemed to prefer to be taught by CL instead of the lecture-style mostly due to the perceived academic and social benefits it generates (Farzaneh \& Nejadansari, 2014; Johnson et al., 2010). In terms of academic benefits, students reported an increased motivation to learn, clear enhanced autonomy and responsibility towards learning, gaining thinking and problemsolving skills, higher levels of understanding of the content, as well as long-term retention. Regarding the social benefits, students seemed to agree that adopting the CL principles led to enjoyment in learning and reduction in anxiety, an increase in confidence, and to a positive relationship among students.

However, the findings generally indicate that some students in all classes expressed some less positive views towards CL. A possible reason for this is that the students were taught some subjects by using CL and other subjects by using lecture-style that made them confused or not sure. Finally, the results show that students' familiarity and experiences with CL could affect their perceptions about its benefits. The percentage of students in Year 11 and Year 12 who had been taught by CL for more than a year is more than the percentage of students in Year 10 who had been taught for less than one semester with some statements. 
Based on the findings mentioned above, it is recommended that cooperative learning should be considered for implementation in Saudi schools instead of lecture-style in order to benefit students academically and socially. However, students need enough time to experience with CL to benefit from all its advantages.

\section{References}

Alaqeel, A. (2013). The Policy and System of Education in Kingdom of Saudi Arabia. Riyadh: Alroshed. (In Arabic)

Alhadi, S. (2013). Management of change higher education institutions towards good quality and excellent performance. Arab Journal for Quality Assurance in Higher Education, (11), 243-305. (In Arabic)

Alhogail, S. (2011). The System and Policy of Learning in Saudi Arabia. Riyadh: Alhomady Publishing. (In Arabic)

Aljaser, S. (2002). The Effect of Cooperative Learning on Students' Achievement in Mathematics in Teachers College in Arar City (Master's thesis, University of Umm al-Qura, Saudi Arabia). (In Arabic)

Almaliki, A. (2010). Students' perceptions towards teaching strategies used in Islamic Culture classes in secondary schools. Arabic Studies in Education, (25), 11-30. (In Arabic)

Almufadda, S. (2006). The Impact of Using Cooperative Learning on the Achievement of Grade 11 in Alfiqh Curriculum. Retrieved from http://faculty.ksu.edu.sa/5345/default.aspx (Accessed 26 May 2015). (In Arabic)

Alrehaily, M. (2000). The Effect of Using Cooperative Learning in Science Education on Development Higher Cognitive Abilities with Second Year Intermediate Female Students (Master's thesis, University of King Abdulaziz University, Saudi Arabia). (In Arabic)

Alreshidy, N. (2008). The Effect of Cooperative Learning on Students' Achievements in Mathematics, in Secondary Schools in Hail city (Master's thesis, University of Jordan, Jordan). (In Arabic)

Alsayegh, N. (2007). The changeable leadership in Saudi universities in the light of the rules and regulations of higher education. Paper presented at Arabic Universities, Challenges and Future Prospects Conference, Morocco. (In Arabic)

Aydin, S. (2011). Effect of cooperative learning and traditional methods on students' achievements and identifications of laboratory equipments in science-technology laboratory course. Educational Research and Reviews, 6 (9) 636644.

Barab, S., \& Duffy, T. (2000). From practice fields to communities of practice. In D.H. Jonassen \& S.M. Land (Eds.), Theoretical Foundations of Learning Environments (pp. 25-51). Mahwah, NJ: Lawrence Erlbaum.

Barton, D., \& Tusting, K. (2005). Beyond Communities of Practice: Language Power and Social Context. New York: Cambridge University Press.

Benson, P. (2007). Autonomy in language teaching and learning. Language Teaching, 40 (1), 21-40.

Berrett, D. (2012). Harvard conference seeks to jolt university teaching. The Chronicle of Higher Education. Retrieved from http://chronicle.com/article/Harvard-Seeks-to-Jolt/130683/ (Accessed 20 October 2014).

Blatchford, P., Kutnick, P. \& Baines, E. (2007). Pupil grouping for learning in classrooms: Results from the UK SPRinG Study. Paper presented at the American Educational Research Annual Meeting, Chicago.

Bloom, B., Engelhart, M., Furst, E., Hill, W. \& Krathwohl, D. (1956). Taxonomy of Educational Objectives: The Classification of Educational Goals. Handbook I: Cognitive domain. New York: David McKay Company.

Bryman, A. (2016). Social Research Methods (5 ed.). New York: Oxford University Press.

Bukunola, B. \& Idowu, O. (2012). Effectiveness of cooperative learning strategies on Nigerian junior secondary students' academic achievement in basic Science. British Journal of Education, Society \& Behavioural Science, 2 (3), 307325.

Busher, H., James, N., Piela, A. \& Palmer, A. (2014). Transforming marginalised adult learners' views of themselves: Access to Higher Education courses in England. British Journal of Sociology of Education, 35 (5), 800-817.

Cavanagh, M. (2011). Students' experiences of active engagement through cooperative learning activities in lectures. Active Learning in Higher Education, 12 (1), 23-33.

Crandall, J. (1999). Cooperative learning and affective factors. In J. Arnold (Ed.), Affect in Language Learning (pp.226245). Cambridge: Cambridge University Press.

Dam, L., Eriksson, D. Little, J. Miliander, \& T. Trebbi. (1990). Towards a definition of autonomy. In T. Trebbi (Ed.), Third Nordic Workshop on Developing Autonomous Learning in the FL Classroom. Bergen: University of Bergen. Retrieved from http://www2.warwick.ac.uk/fac/soc/al/research/groups/ellta/circal/dahla/archive/trebbi-1990.pdf (Accessed 26 August 2014).

Deutsch, M. (1949). A theory of cooperation and competition. Human Relations, 2, 129-152.

Duren, P., \& Cherrington, A. (2010). The effects of cooperative group work versus independent practice on the learning of some problem-solving strategies. School Science and Mathematics, 92 (2), 80-83.

Farzaneh, N., \& Nejadansari, D. (2014). Students' attitudes towards using cooperative learning for teaching reading comprehension. Theory and Practice in Language Studies, 4 (2), 287-292. 
Favor, J. (2012). Students' perceptions of long-functioning cooperative teams in accelerated adult degree programs. The Journal of Continuing Higher Education, 60 (3), 157-164.

Fullan, M. (2007). The New Meaning of Educational Change (4 ed.). New York: Teachers College Press.

Gillies, R. (2008). The effects of cooperative learning on junior high school students' behaviours, discourse, and learning during a science-based learning activity. School Psychology International, 29 (3), 328-347.

Gillies, R., \& Khan, A. (2008). The effects of teacher discourse on students' discourse, problem-solving and reasoning during cooperative learning. International Journal of Educational Research, 47(6), 323-340.

Hockenbury, D., \& Hockenbury, S. (2012). Psychology (6 ed.). New York: Worth.

Hughes, J., Jewson, N., \& Unwin, L. (2007). Communities of Practice: Critical Perspectives. London: Routledge.

Idowu, O. (2013). Effect of a Cooperative Learning Technique on the Academic Performance of High (PHD thesis, University of Walden, United States).

Johnson, D. \& Johnson, F. (2014). Joining Together Group Theory and Group Skills. Harlow: Pearson.

Johnson, D. \& Johnson, R. (2008a). Cooperative learning and preventing bullying. The Cooperative Learning Institute, 23 (1), 1-4.

Johnson, D., \& Johnson, R. (2008b). Social Interdependence Theory and Cooperative Learning: the Teacher's Role. In R. M. Gillies, A. Ashman \& J. Terwel (Eds.), The Teacher's Role in Implementing Cooperative Learning in the Classroom (pp. 9-36). New York: Springer.

Johnson, D. \& Johnson, R. (2009). An Educational Psychology Success Story: Social Interdependence Theory and Cooperative Learning. Educational Researcher, 38 (5), 365-379.

Johnson, D, Johnson, R \& Roseth, C. (2010). Cooperative learning in middle schools: Interrelationship of relationships and achievement. Middle Grades Research Journal, 5 (1), 1-18.

Johnson, D., Johnson, R., \& Smith, K. (2007). The state of cooperative learning in postsecondary and professional settings. Educational Psychology Review, 19 (1), 15 - 29.

Kimble, C., Hildreth, P., \& Bourdon, I. (2008). Communities of Practice: Creating Learning Environments for Educators. Geneva: IAP.

Kohonen, V. (1992). Experiential language learning: Second language learning as cooperative learner education. In P. Prudencio \& M. Ortiz (Eds.), Foreign Language English (pp.45-64). Argentina: Secretaría de Educación Pública.

Lave, J., \& Wenger, E., (1991). Situated Learning: Legitimate Peripheral Participation. Cambridge: Cambridge University Press.

Levin, B. (2001). Reforming Education: from Origins to Outcomes. London: Routledge Falmer.

McCauley, V., \& McClelland, G. (2004). Further studies in self-directed learning in physics at the University of Limerick, Ireland. International Journal of Self-Directed Learning, 1 (2), 26 - 37.

Ministry of Education (MOH). (2015). Ministry of Education Website. Retrieved from

https://www.moe.gov.sa/Arabic/Pages/default.aspx\# (Accessed 09 February 2015). (In Arabic)

Muijs, D. \& Reynolds, D. (2011). Effective Teaching: Evidence and Practice (3 ed.). London: SAGE.

Pan, C \& Wu, H. (2013). The Cooperative Learning Effects on English Reading Comprehension and Learning Motivation of EFL Freshmen. English Language Teaching, 6 (5), 13-27.

Pavlov, I. (1934). An attempt at a physiological interpretation of obsessional neurosis and paranoia. Journal of Mental Science, 80, 187-197.

Peterson, S. \& Miller, J. (2004). Comparing the quality of students' experiences during cooperative learning and large-group instruction. The Journal of Educational Research, 97 (3), 123-133.

Piaget, J. (2001). The Child's Conception of Physical Causality. New Brunswick, NJ: Transaction Publishers.

Sarkhouh, A. (2007). The Effect of Teaching Mathematics Based on Cooperative Learning on Achievement Of Intermediate Stage Students in Kuwait (Master's thesis, University of Amman, Jordan). (In Arabic)

Schunk, D. (2014). Learning Theories an Educational Perspective (7 ed.). Essex: PEARSON.

Shaaban, K. (2006). An initial study of the effects of cooperative learning on reading comprehension, vocabulary acquisition, and motivation to read. Reading Psychology, 27 (5), 377-403.

Shaiban, N. (2009). The Effect of Implementing Cooperative Learning Strategy in Teaching some Concepts of Social Science on Academic Achievement Experimental Study on Fourth-Grade Basic Education In Lattakia City (Master's thesis, University of Damascus, Syria). (In Arabic)

Skinner, B. (1938). The Behavior of Organisms. New York: Appleton-Century-Crofts.

Slavin, R. (1995). Cooperative Learning: Theory, Research, and Practice (2 ed.). Boston: Allyn and Bacon.

Smith, R. (2008). Key concepts in ELT: learner autonomy. ELT Journal, 62 (4), 395-6.

Svalberg, A. (2012). Peer interaction, cognitive conflict, and anxiety on a Grammar Awareness course for language teachers. Language Awareness, 21 (1-2), 137-155.

Tan, I., Sharan, S., \& Lee, C. (2007). Group investigation. Effects on achievement, motivation, and perceptions of students in Singapore. Journal of Educational Research, 100 (3), 142-154.

Taylor, L., Davis-Kean, D., \& Malanchuk, O. (2007). Self-esteem, academic self-concept, and aggression at school. Aggressive Behavior, 33 (2), 130-136. 
Thorndike, E. (1932). The Fundamentals of Learning. New York: Teachers College Press.

Tran, V. (2014). The effects of cooperative learning on the academic achievement and knowledge retention. International Journal of Higher Education, 3 (2) 131-140.

Tran, V., \& Lewis, R. (2012). Effects of cooperative learning on students at An Giang University in Vietnam. International Education Studies, 5 (1), 86-99.

VCSMR, P., \& Rao, S. (2013). Encouraging co-operative learning among students, Journal of Business Administration and Education. 2 (1), 21-34.

Vygotsky, L. (1978). Mind in Society: The Development of Higher Psychological Processes. Cambridge: Harvard University Press.

Zakaria, E., Solfitri, T., Daud, Y. \& Abidin, Z. (2013). Effect of cooperative learning on secondary school students' mathematics achievement. Creative Education, 4 (2), 98 - 100.

\section{Appendix}

Table 1. Students' perceptions of academic outcomes

\begin{tabular}{|c|c|c|c|c|c|c|}
\hline $\begin{array}{l}\text { In comparing with lecture style, } \\
\text { using CL method in the class } \\
\text { helped me with..... }\end{array}$ & The class & $\begin{array}{c}\text { Strongly } \\
\text { agree }\end{array}$ & Agree & Not sure & Disagree & $\begin{array}{l}\text { Strongly } \\
\text { disagree }\end{array}$ \\
\hline \multirow{3}{*}{$\begin{array}{l}\text { Understanding the content of } \\
\text { the lesson better that other } \\
\text { teaching methods such as } \\
\text { lecture style }\end{array}$} & Year 10 & $\begin{array}{c}8 \\
(24.2 \%)\end{array}$ & $\begin{array}{c}17 \\
(51.5 \%)\end{array}$ & $\begin{array}{c}5 \\
(15.2 \%)\end{array}$ & $\begin{array}{c}2 \\
(6.1 \%)\end{array}$ & $\begin{array}{c}1 \\
(3.0 \%)\end{array}$ \\
\hline & Year 11 & $\begin{array}{c}12 \\
(38.7 \%)\end{array}$ & $\begin{array}{c}13 \\
(41.9 \%)\end{array}$ & $\begin{array}{c}3 \\
(9.7 \%) \\
\end{array}$ & $\begin{array}{c}1 \\
(3.2 \%) \\
\end{array}$ & $\begin{array}{c}2 \\
(6.5 \%) \\
\end{array}$ \\
\hline & Year 12 & $\begin{array}{c}10 \\
(35.7 \%)\end{array}$ & $\begin{array}{c}13 \\
(46.4 \%)\end{array}$ & $\begin{array}{c}4 \\
(14.3 \%)\end{array}$ & $\begin{array}{c}1 \\
(3.6 \%)\end{array}$ & $\begin{array}{c}0 \\
(0.0 \%)\end{array}$ \\
\hline \multirow[t]{3}{*}{ Thinking skills } & Year 10 & $\begin{array}{c}11 \\
(33.3 \%)\end{array}$ & $\begin{array}{c}13 \\
(39.4 \%)\end{array}$ & $\begin{array}{c}5 \\
(15.2 \%)\end{array}$ & $\begin{array}{c}4 \\
(12.1 \%)\end{array}$ & $\begin{array}{c}0 \\
(0.0 \%)\end{array}$ \\
\hline & Year 11 & $\begin{array}{c}9 \\
(29.0 \%)\end{array}$ & $\begin{array}{c}15 \\
(48.4 \%)\end{array}$ & $\begin{array}{c}5 \\
(16.1 \%) \\
\end{array}$ & $\begin{array}{c}2 \\
(6.5 \%) \\
\end{array}$ & $\begin{array}{c}0 \\
(0.0 \%) \\
\end{array}$ \\
\hline & Year 12 & $\begin{array}{c}8 \\
(28.6 \%)\end{array}$ & $\begin{array}{c}13 \\
(46.4 \%)\end{array}$ & $\begin{array}{c}4 \\
(14.3 \%)\end{array}$ & $\begin{array}{c}3 \\
(10.7 \%)\end{array}$ & $\begin{array}{c}0 \\
(0.0 \%)\end{array}$ \\
\hline \multirow[t]{3}{*}{ Problem solving skills } & Year 10 & $\begin{array}{c}10 \\
(30.3 \%) \\
\end{array}$ & $\begin{array}{c}12 \\
(36.4 \%) \\
\end{array}$ & $\begin{array}{c}7 \\
(21.2 \%) \\
\end{array}$ & $\begin{array}{c}2 \\
(6.1 \%) \\
\end{array}$ & $\begin{array}{c}2 \\
(6.1 \%) \\
\end{array}$ \\
\hline & Year 11 & $\begin{array}{c}7 \\
(22.6 \%)\end{array}$ & $\begin{array}{c}13 \\
(41.9 \%)\end{array}$ & $\begin{array}{c}10 \\
(32.3 \%)\end{array}$ & $\begin{array}{c}1 \\
(3.2 \%)\end{array}$ & $\begin{array}{c}0 \\
(0.0 \%)\end{array}$ \\
\hline & Year 12 & $\begin{array}{c}8 \\
(28.6 \%)\end{array}$ & $\begin{array}{c}11 \\
(39.3 \%)\end{array}$ & $\begin{array}{c}9 \\
(32.1 \%)\end{array}$ & $\begin{array}{c}0 \\
(0.0 \%)\end{array}$ & $\begin{array}{c}0 \\
(0.0 \%)\end{array}$ \\
\hline \multirow{3}{*}{$\begin{array}{l}\text { Retention of the lesson content } \\
\text { (memory) }\end{array}$} & Year 10 & $\begin{array}{c}11 \\
(33.3 \%) \\
\end{array}$ & $\begin{array}{c}15 \\
(45.5 \%) \\
\end{array}$ & $\begin{array}{c}4 \\
(12.1 \%) \\
\end{array}$ & $\begin{array}{c}2 \\
(6.1 \%) \\
\end{array}$ & $\begin{array}{c}1 \\
(3.0 \%) \\
\end{array}$ \\
\hline & Year 11 & $\begin{array}{c}8 \\
(25.8 \%)\end{array}$ & $\begin{array}{c}15 \\
(48.4 \%)\end{array}$ & $\begin{array}{c}4 \\
(12.9 \%)\end{array}$ & $\begin{array}{c}4 \\
(12.9 \%)\end{array}$ & $\begin{array}{c}0 \\
(0.0 \%)\end{array}$ \\
\hline & Year 12 & $\begin{array}{c}6 \\
(21.4 \%)\end{array}$ & $\begin{array}{c}14 \\
(50.0 \%)\end{array}$ & $\begin{array}{c}3 \\
(10.7 \%)\end{array}$ & $\begin{array}{c}4 \\
(14.3 \%)\end{array}$ & $\begin{array}{c}1 \\
(3.6 \%)\end{array}$ \\
\hline \multirow{3}{*}{$\begin{array}{l}\text { Increasing my learning } \\
\text { motivation }\end{array}$} & Year 10 & $\begin{array}{c}5 \\
(15.2 \%)\end{array}$ & $\begin{array}{c}17 \\
(51.5 \%)\end{array}$ & $\begin{array}{c}4 \\
(12.1 \%)\end{array}$ & $\begin{array}{c}5 \\
(15.2 \%) \\
\end{array}$ & $\begin{array}{c}2 \\
(6.1 \%) \\
\end{array}$ \\
\hline & Year 11 & $\begin{array}{c}9 \\
(29.0 \%)\end{array}$ & $\begin{array}{c}13 \\
(41.9 \%)\end{array}$ & $\begin{array}{c}5 \\
(16.1 \%)\end{array}$ & $\begin{array}{c}3 \\
(9.7 \%)\end{array}$ & $\begin{array}{c}1 \\
(3.2 \%)\end{array}$ \\
\hline & Year 12 & $\begin{array}{c}7 \\
(25.0 \%) \\
\end{array}$ & $\begin{array}{c}12 \\
(42.9 \%) \\
\end{array}$ & $\begin{array}{c}6 \\
(21.4 \%) \\
\end{array}$ & $\begin{array}{c}3 \\
(10.7 \%) \\
\end{array}$ & $\begin{array}{c}0 \\
(0.0 \%) \\
\end{array}$ \\
\hline \multirow{2}{*}{$\begin{array}{l}\text { Encourage me to be an } \\
\text { autonomous learner }\end{array}$} & Year 10 & $\begin{array}{c}7 \\
(21.2 \%)\end{array}$ & $\begin{array}{c}15 \\
(45.5 \%)\end{array}$ & $\begin{array}{c}6 \\
(18.2 \%)\end{array}$ & $\begin{array}{c}3 \\
(9.1 \%) \\
\end{array}$ & $\begin{array}{c}2 \\
(6.1 \%) \\
\end{array}$ \\
\hline & Year 11 & $\begin{array}{c}10 \\
(32.3 \%)\end{array}$ & $\begin{array}{c}13 \\
(41.9 \%)\end{array}$ & $\begin{array}{c}4 \\
(12.9 \%) \\
\end{array}$ & $\begin{array}{c}3 \\
(9.7 \%) \\
\end{array}$ & $\begin{array}{c}1 \\
(3.2 \%) \\
\end{array}$ \\
\hline
\end{tabular}




\begin{tabular}{|c|c|c|c|c|c|c|}
\hline & Year 12 & $\begin{array}{c}6 \\
(21.4 \%)\end{array}$ & $\begin{array}{c}17 \\
(60.7 \%)\end{array}$ & $\begin{array}{c}3 \\
(10.7 \%)\end{array}$ & $\begin{array}{c}1 \\
(3.6 \%)\end{array}$ & $\begin{array}{c}1 \\
(3.6 \%)\end{array}$ \\
\hline \multirow{3}{*}{$\begin{array}{c}\text { Increasing my achievement test } \\
\text { scores compared with lecture } \\
\text { style method }\end{array}$} & Year 10 & 5 & 7 & 17 & 3 & 1 \\
& & $(15.2 \%)$ & $(21.2 \%)$ & $(51.5 \%)$ & $(9.1 \%)$ & $(3.0 \%)$ \\
\cline { 2 - 7 } & Year 11 & 10 & 13 & 6 & 2 & 0 \\
\cline { 2 - 7 } & $(32.3 \%)$ & $(41.9 \%)$ & $(19.4 \%)$ & $(6.5 \%)$ & $(0.0 \%)$ \\
\cline { 2 - 7 } & Year 12 & 7 & 15 & 4 & 1 & 1 \\
$(25.0 \%)$ & $(53.6 \%)$ & $(14.3 \%)$ & $(3.6 \%)$ & $(3.6 \%)$ \\
\hline
\end{tabular}

Table 2. Students' perceptions of social outcomes

\begin{tabular}{|c|c|c|c|c|c|c|}
\hline $\begin{array}{l}\text { In comparing with lecture style, } \\
\text { using CL method in the class } \\
\text { helped me with...... }\end{array}$ & The class & $\begin{array}{c}\text { Strongly } \\
\text { agree }\end{array}$ & Agree & Not sure & Disagree & $\begin{array}{l}\text { Strongly } \\
\text { disagree }\end{array}$ \\
\hline \multirow[t]{3}{*}{ Interpersonal relationships } & Year 10 & $\begin{array}{c}17 \\
(51.5 \%)\end{array}$ & $\begin{array}{c}9 \\
(27.3 \%)\end{array}$ & $\begin{array}{c}4 \\
(12.1 \%)\end{array}$ & $\begin{array}{c}0 \\
(0.0 \%)\end{array}$ & $\begin{array}{c}3 \\
(9.1 \%)\end{array}$ \\
\hline & Year 11 & $\begin{array}{c}15 \\
(48.4 \%)\end{array}$ & $\begin{array}{c}11 \\
(35.5 \%)\end{array}$ & $\begin{array}{c}3 \\
(9.7 \%)\end{array}$ & $\begin{array}{c}1 \\
(3.2 \%)\end{array}$ & $\begin{array}{c}1 \\
(3.2 \%)\end{array}$ \\
\hline & Year 12 & $\begin{array}{c}13 \\
(46.4 \%)\end{array}$ & $\begin{array}{c}9 \\
(32.1 \%)\end{array}$ & $\begin{array}{c}4 \\
(14.3 \%)\end{array}$ & $\begin{array}{c}2 \\
(7.1 \%)\end{array}$ & $\begin{array}{c}0 \\
(0.0 \%)\end{array}$ \\
\hline \multirow{3}{*}{ Increasing my self-esteem } & Year 10 & $\begin{array}{c}10 \\
(30.3 \%)\end{array}$ & $\begin{array}{c}15 \\
(45.5 \%)\end{array}$ & $\begin{array}{c}4 \\
(12.1 \%)\end{array}$ & $\begin{array}{c}3 \\
(9.1 \%)\end{array}$ & $\begin{array}{c}1 \\
(3.0 \%)\end{array}$ \\
\hline & Year 11 & $\begin{array}{c}11 \\
(35.5 \%)\end{array}$ & $\begin{array}{c}14 \\
(45.2 \%)\end{array}$ & $\begin{array}{c}6 \\
(19.4 \%)\end{array}$ & $\begin{array}{c}0 \\
(0.0 \%)\end{array}$ & $\begin{array}{c}0 \\
(0.0 \%)\end{array}$ \\
\hline & Year 12 & $\begin{array}{c}12 \\
(42.9 \%)\end{array}$ & $\begin{array}{c}10 \\
(35.7 \%)\end{array}$ & $\begin{array}{c}4 \\
(14.3 \%)\end{array}$ & $\begin{array}{c}2 \\
(7.1 \%)\end{array}$ & $\begin{array}{c}0 \\
(0.0 \%)\end{array}$ \\
\hline \multirow[t]{3}{*}{ Reducing anxiety } & Year 10 & $\begin{array}{c}7 \\
(21.2 \%)\end{array}$ & $\begin{array}{c}19 \\
(57.6 \%)\end{array}$ & $\begin{array}{c}4 \\
(12.1 \%)\end{array}$ & $\begin{array}{c}3 \\
(9.1 \%)\end{array}$ & $\begin{array}{c}0 \\
(0.0 \%)\end{array}$ \\
\hline & Year 11 & $\begin{array}{c}9 \\
(29.0 \%)\end{array}$ & $\begin{array}{c}15 \\
(48.4 \%)\end{array}$ & $\begin{array}{c}5 \\
(16.1 \%)\end{array}$ & $\begin{array}{c}2 \\
(6.5 \%)\end{array}$ & $\begin{array}{c}0 \\
(0.0 \%)\end{array}$ \\
\hline & Year 12 & $\begin{array}{c}7 \\
(25.0 \%)\end{array}$ & $\begin{array}{c}14 \\
(50.0 \%)\end{array}$ & $\begin{array}{c}6 \\
(21.4 \%)\end{array}$ & $\begin{array}{c}1 \\
(3.6 \%)\end{array}$ & $\begin{array}{c}0 \\
(0.0 \%)\end{array}$ \\
\hline \multirow{3}{*}{$\begin{array}{c}\text { Increasing my enjoyment in } \\
\text { learning }\end{array}$} & Year 10 & $\begin{array}{c}12 \\
(36.4 \%)\end{array}$ & $\begin{array}{c}14 \\
(42.4 \%)\end{array}$ & $\begin{array}{c}4 \\
(12.1 \%)\end{array}$ & $\begin{array}{c}3 \\
(9.1 \%)\end{array}$ & $\begin{array}{c}0 \\
(0.0 \%)\end{array}$ \\
\hline & Year 11 & $\begin{array}{c}13 \\
(41.9 \%)\end{array}$ & $\begin{array}{c}11 \\
(35.5 \%)\end{array}$ & $\begin{array}{c}6 \\
(19.4 \%)\end{array}$ & $\begin{array}{c}1 \\
(3.2 \%)\end{array}$ & $\begin{array}{c}0 \\
(0.0 \%)\end{array}$ \\
\hline & Year 12 & $\begin{array}{c}8 \\
(28.6 \%)\end{array}$ & $\begin{array}{c}15 \\
(53.6 \%)\end{array}$ & $\begin{array}{c}3 \\
(10.7 \%)\end{array}$ & $\begin{array}{c}1 \\
(3.6 \%)\end{array}$ & $\begin{array}{c}1 \\
(3.6 \%)\end{array}$ \\
\hline
\end{tabular}

